\title{
Block Movements in the Pennines and South Wales and their Association with Landslides
}

\author{
L. J. Donnelly* $\ddagger$ K. J, Northmore $\ddagger$ \& H. J. Siddle $\dagger$ \\ *IMC Group Consulting Ltd, PO Box 18, Huthwaite, Sutton-in-Ashfield, Notts, UK, NG17 2NS \& Research fellow, \\ British Geological Survey. Tel: 01623441444 Fax: 01623440 333. Email: ldonnelly@imcgroup.co.uk \\ ‡ British Geological Survey, Keyworth, Nottingham, UK, NG12 5GG. Tel: 0115936 3100. Fax: 0115936 3200. Email \\ K.Northmore@BGS.ac.uk \\ †Halcrow Group Ltd, 31-33 Newport Road, Cardiff, UK, CF24 0AB. Tel: 0292049 7000. Fax: 0292040 6501. Email: \\ siddlehj@halcrow.com
}

\begin{abstract}
Fault scarps and graben features indicative of slope deformation have been observed adjacent to the rear scarps of landslides and on moorland plateaux in the Pennines. The scarps are distinct, up to $2 \mathrm{~m}$ high and can be traced for a maximum distance of approximately $400 \mathrm{~m}$. These severely reduce the strength of the rock mass, enable groundwater to be channelled onto the upper valley slopes and may have played an important role in the initiation of first-time slope failures, and in the reactivation of older landslides. These features are similar to those recently described on the interfluves of the South Wales Coalfield valleys (Donnelly et al., 2000a, 2000b), and are consistent with those described as 'block movements' elsewhere in the world. Those in South Wales have been interpreted, by some previous investigators, as being generated during mining subsidence. However, in the Pennines, the slope and plateaux movements occur in the Namurian (Upper Carboniferous) sedimentary sequences where there has been no mining and it is therefore evident that other mechanisms are involved. In both South Wales and the Pennines steep-sided valleys have incised the moorland plateaux which in both cases are capped by strong, well-jointed cap rocks. These have exposed the underlying, much weaker, fissile mudstones which form the middle and lower slopes. These block movements in the Pennines are documented, discussed and compared with those in South Wales.
\end{abstract}

\section{Introduction}

Multiple sets of grabens have been observed and documented (Donnelly 1994 and Donnelly et al., 2000a, 2000b) on the high moorland plateaux of the northern part of the South Wales Coalfield. These are striking features of the landscape and individual scarps may reach $4 \mathrm{~m}$ high and $4 \mathrm{~km}$ in length. Typical examples can be found in the vicinity of the Darren Ddu, East Pentwyn and Bournville landslides in the Ebbw Fach Valley (NGR SO 198060, 207075 and 206068), although many other examples also exist (Conway et al., 1980, Halcrow, 1989). The generation of these features and their association with landslides is not fully understood. Many previous researchers have tended to attribute them to coal mining which has been practised in the area since at least the mid 1800s to the 1980s. However, these fault scarps differ significantly from other cases of mining subsidence induced features which have been investigated throughout the coalfields of the UK, due to their vast magnitude and extent (Donnelly 1994, 2000c). Furthermore, the existence of these faults scarps, graben and landslides are indicative of horizontal extension (or 'spreading') of the plateaux surface far in excess of that which could be induced by mining subsidence alone. Therefore, it has been suggested that other processes may have been involved in the formation of the graben (Donnelly et al., 2000a, 2000b and Hutchinson 2001) but this has been difficult to prove.

Fault scarps and graben have also been observed in the Derbyshire Pennines. These exist in geomorphological settings that are similar to the examples in South Wales; on moorland plateaux, in the interfluves of deeply incised valleys and in close proximity to the rear scarps of landslides. These occur in rocks of Namurian (Upper Carboniferous) age that have not been undermined and therefore processes other than mining subsidence must have generated these structures. Observations of deep-seated movements producing reactivated faults, graben and fissures (open joints) and affecting plateaux behind the rear scarps of landslides, are increasing. For example, these have now been documented in the Northern Apennines (Cancelli \& Pellegrini 1987) and the Isle of Portland (Brunsden et al., 1996). Recent re-mapping surveys by the British Geological Survey indicate that similar movements may also be present in high relief areas in Lancashire and Gloucestershire. However, it has been suggested by Hutchinson, (2001) that these movements differ from the 'classic' earth and rock spreads described by Cruden \& Varnes (1996) and Crozier (1986), and their classification and terminology as 'spreading' failures warrants further consideration. The objectives of this paper are to document for the first time the grabens and distinctive features of 'spreading' and 'block movements' in the Pennines, to compare them with those in South Wales 
and to explain their apparent association with landsliding. This paper suggests possible mechanisms for their generation such as valley de-glaciation and gravitational stress relief of the valley slopes, although this requires further investigations. The classification and terminology of such horizontal ground movements are also briefly discussed.

\section{Location and Geology of the Pennine Graben}

Although some informative research has been undertaken on landslides in the Derbyshire Pennines, particularly on the more well-known examples of Mam Tor and Alport Castle; (Skempton et al., 1989, Doornkamp 1990; Johnson and Vaughan, 1993; Cripps \& Hird 1997; Albabbagh \& Cripps 1987, and Waltham \& Dixon 2000) many landslides have not been documented in detail. One such area with grabens and fault scarps occurs near Gillot Hey Farm, hereafter referred to as the 'Gillot Hey landslide' (NGR SK1450 8990). The landslide is located, on Rowlee Pasture, approximately $1 \mathrm{~km}$ southeast of the Alport Castle Landslide (NGR SK1420 9140). The region is sparsely populated and is one of the most elevated and wettest parts of upland Britain, used only for pasturage, forestry, grouse moorland and recreation. The Alport Dale valley and Woodlands valley have deeply incised the upland plateau. The sub-aerial and glacial denudation of the valley slopes may have proceeded without interruption for over a million years (McArthur 1977). The graben are situated on a spur above Gillot Hey Farm, north of the A57 'Snake Pass' (ManchesterSheffield) road, at the junction of Woodlands Valley and Alport Dale (Figure 1).

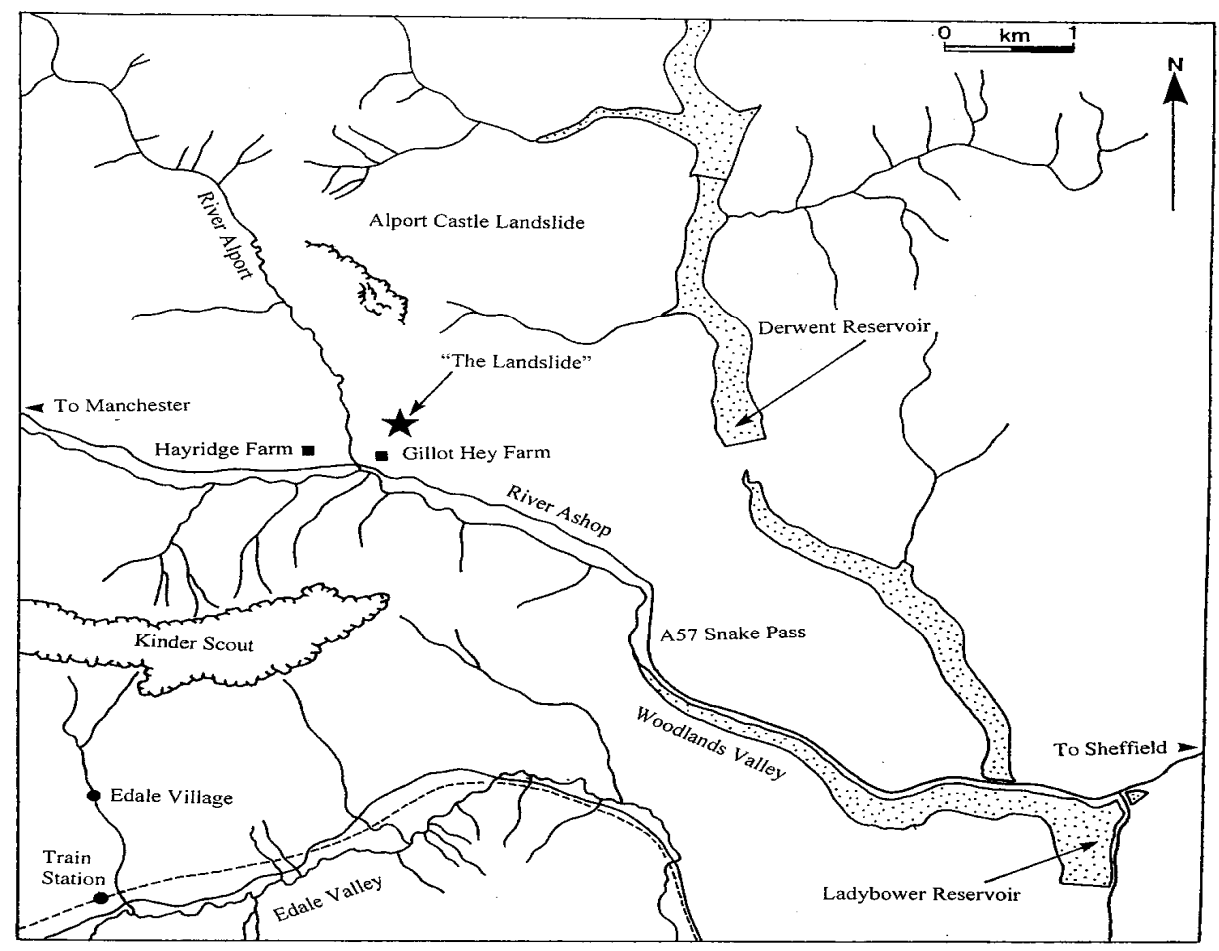

Figure 1. Location of the Gillot Hey Landslide and graben in the Derbyshire Pennines

The strata in the vicinity of the Gillot Hey Landslide are Upper Carboniferous in age and belong to the Millstone Grit Series (Namurian). They consist predominantly of sandstone, siltstone and shale and have been classified into three stratigraphical formations of the Kinderscoutian (Stevenson and Gaunt 1971). The 'Shale Grit' occupies the upper slopes and consists of strong, well-jointed, massive sandstone with shale bands. These are underlain by the 'Mam Tor Beds,' a sequence of mudrocks, inter-bedded with thin sandstone beds. The lowest formation, the 'Edale Shales' outcrops in the valley floors and on the middle and lower slopes.

\section{Characteristics of the Gillot Hey Landslide and Graben}

The Gillot Hey Landslide is a complex rock slide-earthflow with rockfall debris incorporated in and covering the slip mass. The rear scarp is approximately $10 \mathrm{~m}$ high and $60 \mathrm{~m}$ long. The middle and lower slopes consist of a boulder-strewn slipped mass, with well-defined earthflow lobes at the toe, parts of which have overridden a dry stone wall and field boundary fence. Groundwater flows through the Shale Grit and Mam Tor Beds from the moorland catchment to emerge as springs at the junction of the Edale Shales and overlying 
Mam Tor Beds, forming waterlogged ground near the toe of the landslide. Small streams issuing from the landslide toe flow in a south-westerly direction into the River Alport. The geological configuration and the role of the weak and easily weathered Edale Shales in promoting instability and deep-seated landslides is described by Stewart and Cripps (1983).

The well-jointed, competent sandstone units and weak interbedded shales of the Shale Grit sequence are exposed in the backscarp of the landslide. Two geological faults are exposed in this rear scarp and correspond to topographic fault scarps defining a graben on the moorland surface upslope of the landslide. These scarps are oriented perpendicular to the face of the landslide backscarp. When the landslide is viewed in an easterly direction, from the A57 'Snake Pass' road, five fault scarps are visible which define two graben structures, Graben A and Graben B and a single fault scarp (or step) (Figure 2).
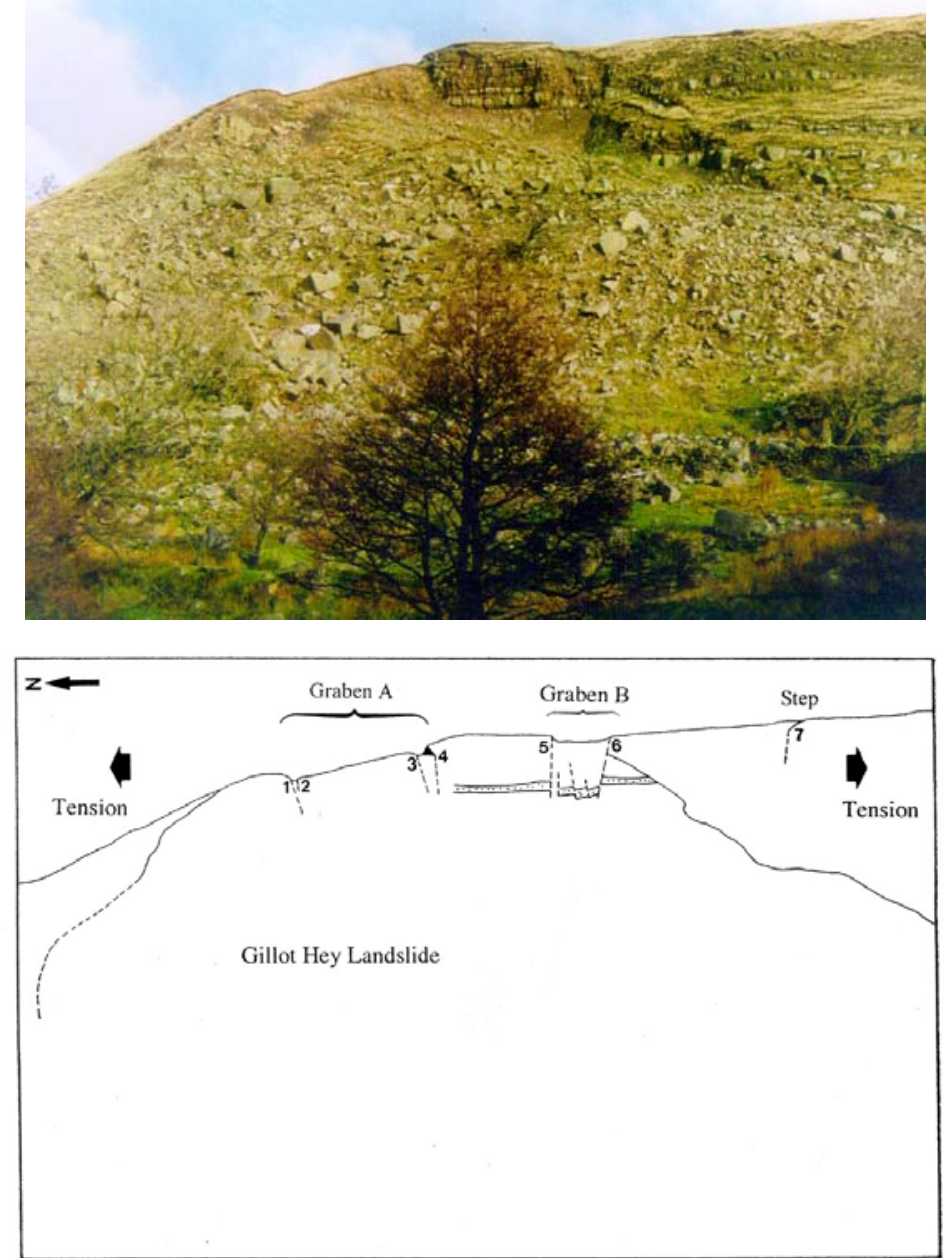

Figure 2. Two graben and a single fault scarp exposed in the backscarp of the Gillot Hey Landslide, at Rowlee Pasture on the 'A57' Snake Pass (Manchester-Sheffield) road.

Graben A, is approximately $23 \mathrm{~m}$ wide, and is defined by faults 1 and 4 . These are located on the western (lower) flank of the landslide crest. Fault zone 1 is composed of two sub-scarps, with opposing directions of dip that define a small secondary graben approximately $3.0 \mathrm{~m}$ wide. The individual scarps form distinct features, $0.3 \mathrm{~m}$ high, and can be traced for a distance of $30 \mathrm{~m}$ to the north-east. The fault zone $3 / 4$, defining the upper limit of Graben A, is located towards the top of the landslide and comprises a main fault scarp 1.0 $\mathrm{m}$ high that trends parallel to faults 1 and 2 .

Graben B, is located at the crown of the landslide and comprises two fault scarps, 5 and 6, approximately $1 \mathrm{~m}$ high. The fault scarps are slightly divergent, separated by a distance of $6 \mathrm{~m}$ where exposed at the landslide backscarp, increasing to $15 \mathrm{~m}$ separation $30 \mathrm{~m}$ beyond the crown. The faults are vertical with $1 \mathrm{~m}$ of normal displacement and are each defined by a 0.1-0.5 $\mathrm{m}$ wide weathered and disintegrated seepage zone of closely-spaced interlocking fissures. A $60 \mathrm{~mm}$ wide central zone of wet clay and oxidised, clayey sand represents fault gouge. The faults reduce the strength of the rock mass, enable groundwater to be channelled onto the face of the backscarp and may have been a significant factor in the initiation of a landslide at this locality and influencing subsequent stability conditions (Figure 3). 

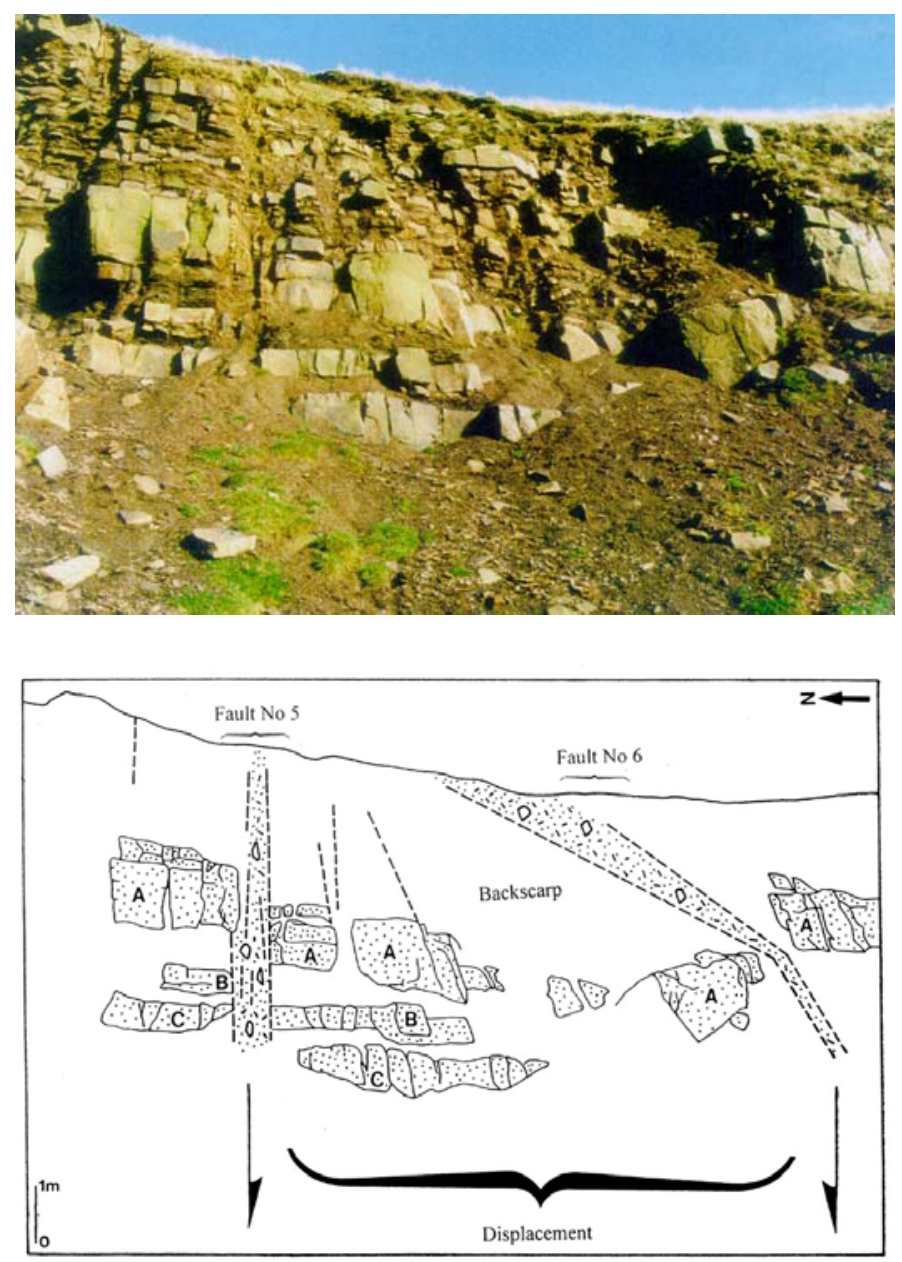

Figure 3. Vertical displacement along two faults exposed in the backscarp of the Gillot Hey Landslide. These correspond to scarps (5 and 6 on figures 2 and 4) on the plateau beyond the landslide crown.

Approximately $28 \mathrm{~m}$ south of Graben B, a single fault scarp (or step) $0.3 \mathrm{~m}$ high and $35 \mathrm{~m}$ long trends subparallel to faults 1 to 6 in a north-easterly direction (fault 7 on figure 2). This is a much more subdued topographic feature in comparison to the other fault scarps and may represent the eroded remnants of an ‘older’ fault scarp.

The most extensive fault scarp occurs approximately $40 \mathrm{~m}$ upslope of the landslide crown (fault 8 on Figure 4). This is a distinct, linear, high-angled, up-hill facing (or antislope) scarp reaching $2 \mathrm{~m}$ in height and $400 \mathrm{~m}$ in length and oriented approximately parallel to Woodlands Valley. All of the other scarps and graben structures terminate at this feature. This particular scarp is similar to other upslope-facing scarps recently documented in the South Wales moorland plateaux (Donnelly et al., 2000a, 2000b).

\section{Formation of the Graben and Block Spreading of the Plateaux}

The graben and fault scarps in the vicinity of the Gillot Hey Landslide are not as extensive, or prominent as the South Wales examples. However, they do share several similarities. In both areas they occur on the interfluves of upland, moorland plateaux between deeply incised valleys that have undergone glacial and periglacial weathering and erosion and recent river downcutting. Lithological sequences are also similar; with strong, well-jointed sandstones forming the cap rock, overlying much weaker shales and siltstones of the lower/middle slopes and valley floors. Although the origin of these graben and fault structures in the Pennines and South Wales currently remain speculative, it is likely that they have influenced the occurrence of landslides on the plateau crests. 


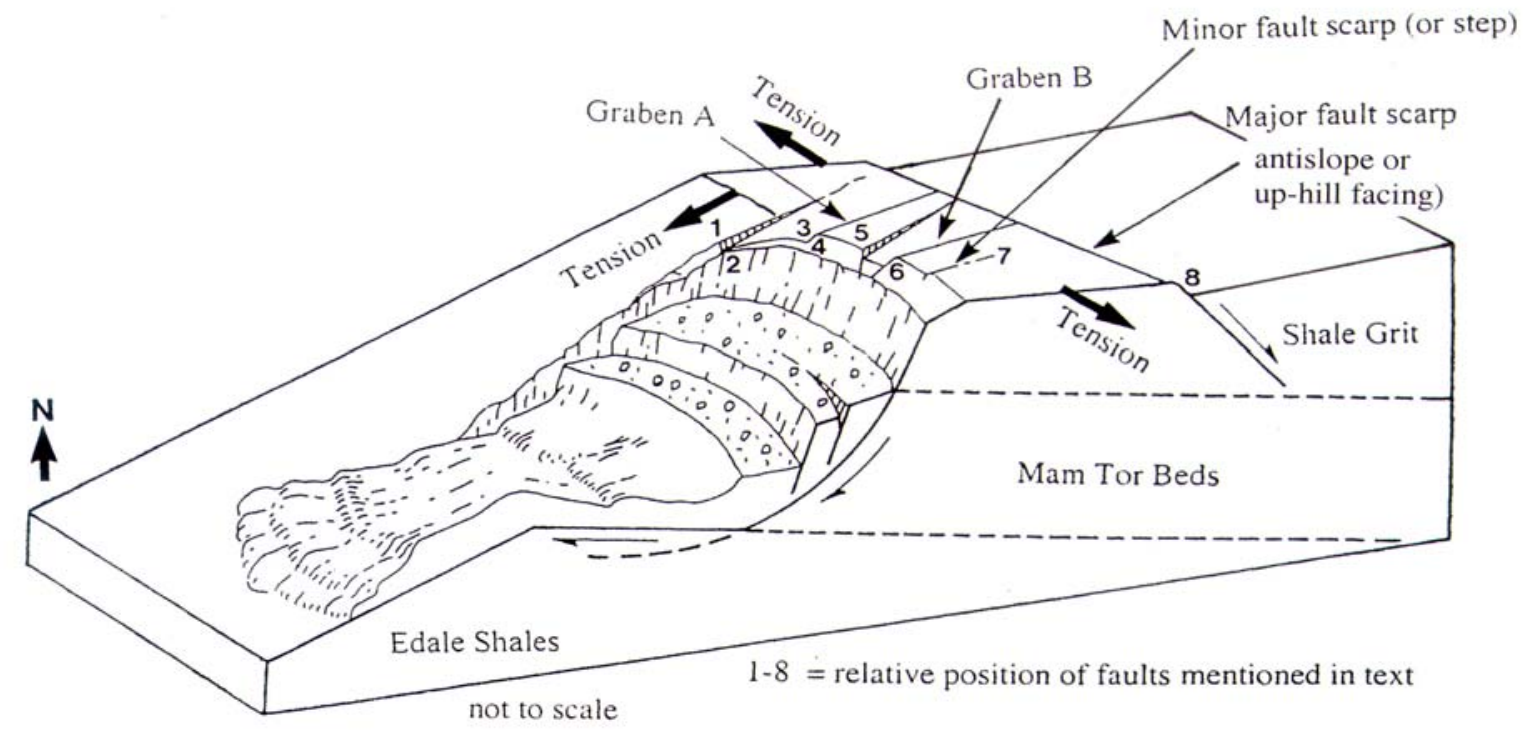

Figure 4. Diagrammatic representation of the Gillot Hey Landslide, graben and fault scarps which illustrate the horizontal movements (spreading) of the plateaux and their influence of the stability of the landslide.

During the Anglian glaciation (480K-420K years BP) in the Pennines and the Anglian and Devensian glaciations (71K-10K years BP) in South Wales, the valley sides would have remained relatively stable, supported by glacier and ground ice. On retreat of the valley glaciers, glacial stress relief of the valley slopes would have been accompanied by periglacial weathering, weakening and erosion of the mudstone and shale sequences underlying the sandstone caprocks. Rapid river erosion and downcutting would have further contributed to stress relief of the adjacent slopes. Such conditions would have facilitated instability and the development of landslides in the weaker argillaceous strata forming the lower and middle valley sides. These processes would have further reduced support of the overlying sandstones, causing dilation of joints and fissures and promoting cambering and failure of the sandstone strata at the plateaux margins. In addition to stress relief, the melting of ground ice is likely to have resulted in increased pore pressures within the argillaceous beds underlying the capping sandstone strata. This may have been a significant factor in the initiation of deep-seated landslides, plastic deformation and 'squeezing' of the shales/mudstones beneath the mass of capping sandstone. Under these conditions, some horizontal extension (or 'spreading') and cambering of the sandstones at the plateaux rims would have been exacerbated and accompanied by disturbance (deformation and bulging) of the argillaceous strata forming the valley sides and floors. It would seem reasonable that the extensional movements of the jointed sandstone strata are reflected in the formation of grabens and prominent plateau scarps, possibly due to reactivation along existing fault planes.

Valley bottom and valley side disturbances are present in several of the Pennine valleys. These appear to be due to a combination of factors including stress relief, moisture take-up by the shales, artesian water pressure, valley-notch concentrations of stresses or frozen ground conditions (Knill 1970 and Higginbottom and Fookes 1971). Many of the dams that have been constructed in the Pennines have revealed spectacular bulges during excavations for the foundations. For instance, during the construction of the foundations for the Howden and Ladybower Dams around 1903, less than $3 \mathrm{~km}$ east of the Gillot Hey Landslide, valley bulges were observed to a depth of at least $20 \mathrm{~m}$ below ground level. At the Ladybower Dam, the valley bulging fold was present to approximately $60 \mathrm{~m}$ below ground level. In the case of the Boothwood Dam intense cambering was observed and in similar conditions a landslide was induced during the construction for the Thuscross Dam to the west of Harrogate. Perhaps rather surprisingly, there appears to be no documented evidence of valley side and valley bottom deformation and bulging in the South Wales valleys.

Reactivated faults scarps and graben similar to the Pennines and South Wales have been documented in recently deglaciated terranes, such as Sweden; (Lagerback 1979), Finland (Kujansuu 1964), Norway (Morner 1978), Russia, (Lundqvist and Lagerback 1976) and Scotland (Ringrose 1987). In these regions the fault scarps have been interpreted as being due to de-glaciation, differential isostatic rebound or neotectonic processes. Similar conclusions have also been reached in British Colombia (Bovis 1982) where uphill facing fault scarps, fissures and graben, have formed due to dilatancy of the rock mass discontinuities following 
glacial retreat. Evidence also exists which suggests that some scarps were responsible for palaeo-seismic events, (Davenport et. al. 1989 and Ringrose 1987). It is possible that the features described in this paper are of a similar origin. In the case of South Wales, these features may have been exacerbated by subsidence induced by relatively recent mining (Figure 5).

\section{The Classification of Lateral Spreading}

Accurate and precise classification and agreed terminology for landslide descriptions are essential to facilitate inter-communication. Several schemes have been suggested and the morphological classifications by Cruden \& Varnes (1996) and Hutchinson (1988) are perhaps the most widely accepted. Hutchinson (2001) has suggested that the use of the term 'lateral spreading' to describe the South Wales graben and plateaux movements are likely to lead to confusion. This may be due to the possibility that most of the spreading involving jointed, competent rock masses described in the literature (such as those observed in Eastern Europe) usually consist of widely separated blocks 'spreading' down shallow slopes without the development of a distinct shear surface.
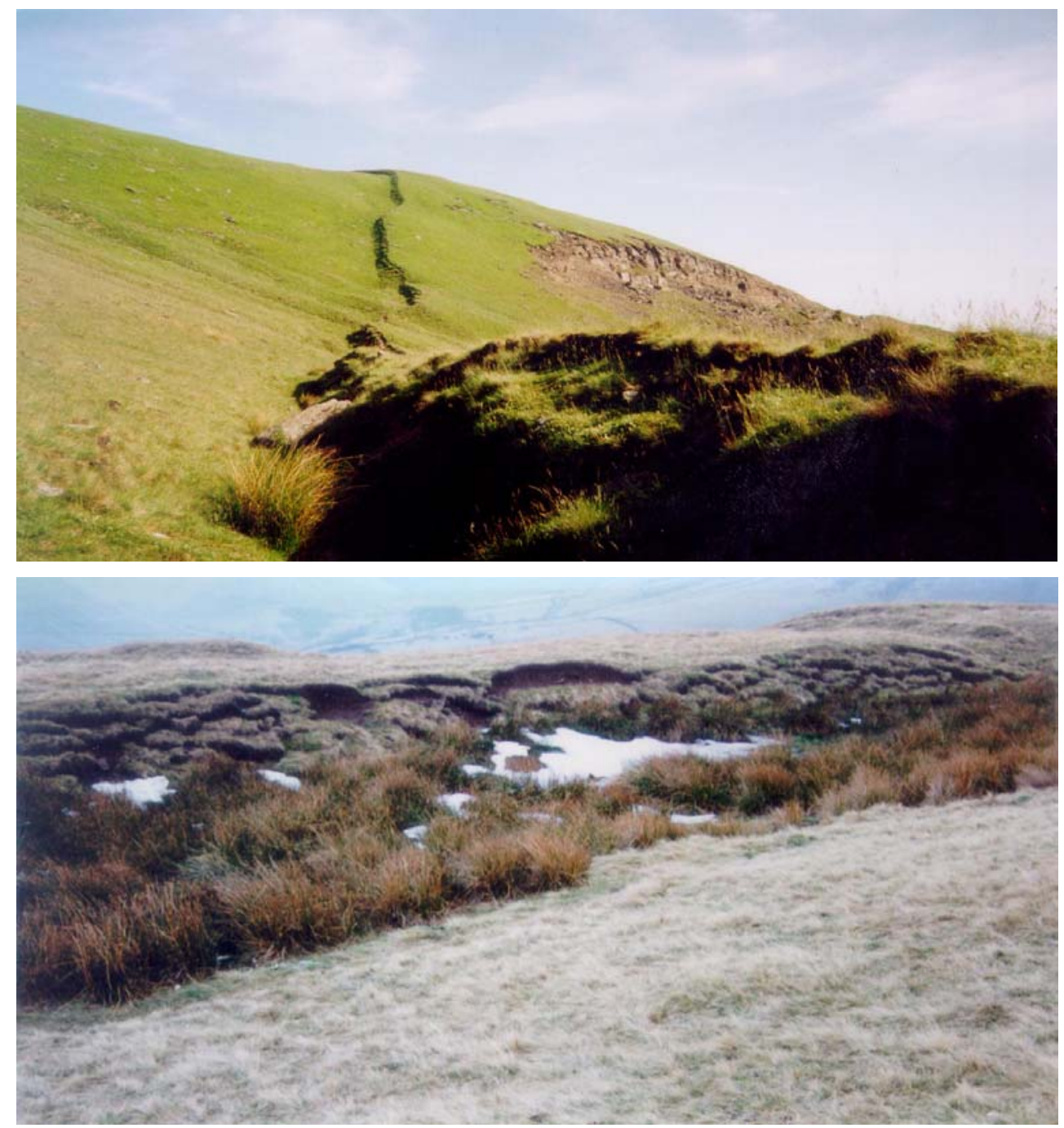

Figure 5. (Upper) A typical South Wales reactivated fault scarp (the Tableland Fault), 3-4 m high and 4 km long, an uphill facing scarp on moorland plateaux beyond the crown of the Darren Goch Landslide in the Garw Valley. This may have been exacerbated by mining subsidence. (Lower) A high-angled, distinct $2 \mathrm{~m}$ high and $400 \mathrm{~m}$ long, uphill facing fault scarp on moorland plateaux beyond the crown of the Gillot Hey Landslide in the Derbyshire Pennines. This area has not been undermined and therefore other mechanisms must be involved. Graben B (faults 5 and 6 on figures 2 and 4) can be seen in the middle distance beyond the fault scarp.

These blocks also 'sink' and 'rotate' into the underlying weaker rock on separation, rather than undergoing 'brittle' displacement along fault planes as seen in the Pennines and South Wales valleys. The 'sackung' or 'sags' described by Hutchinson (1988) may show some similarities with the features observed in South Wales and the Pennines (i.e. upslope-facing scarps). However, as pointed out by Cruden \& Varnes (1996) 
sags may also indicate a variety of movements including slides, spreads and topples. In South Wales and the Pennines the features clearly result from a 'lateral extension' (or 'lateral movement') of the strong, plateaux cap rock, although the processes involved are not fully understood. These appear to fall into the category of 'complex spreads' as described by Cruden \& Varnes (1996) and Brunsden at al., (1996). However, the terms 'block' or 'rock' also apply, and a therefore the most appropriate term to describe these features may be 'complex block spreads' or 'complex rock block spreads.'

\section{Conclusions}

The purpose of this paper has been to draw attention to, and to document, the occurrence of grabens beyond the rear scarp of a landslide (named the Gillot Hey landslide after a near by farm), on moorland plateaux, in rocks of Namurian age in the Derbyshire Pennines. These reach $2 \mathrm{~m}$ high, $400 \mathrm{~m}$ long and are indicative of 'lateral extension' or 'spreading' of the plateaux. Similar features have been recently documented on the interfluves of the South Wales Coalfield, but it has been difficult to determine their origin since ground movements have been complicated by at least 200 years of intense coal mining and subsidence. Therefore, processes other than subsidence must have been responsible for the generation of the Pennine grabens since mining has not been practised. The origin of these graben and fault scarps in the Pennines and South Wales currently remains speculative. However, it is likely that the valley sides would have been supported and confined by glacier and ground ice. On retreat, several complex processes may have facilitated the instability of the valley sides. These may have involved; periglacial weathering, weakening and erosion of the mudstones/shale sequences underlying the sandstone cap rocks, rapid river erosion and downcutting, gravitational stress-relief, elevated pore-fluid pressures within argillaceous beds, moisture take-up by the shales, artesian water pressures, valley notch stress concentrations, cambering and valley bulging. These processes may have been significant in the initiation of deep-seated landslides and the plastic deformation or 'squeezing' of the shales/mudstone beneath the mass of capping sandstones. Under these conditions, 'horizontal extension' (or 'spreading') may have occurred. The extension of well-jointed, competent sandstone cap rocks are reflected in the formation of graben, reactivation of faults (scarps) and dilation of joints (fissures). Several centuries of coal mining and subsidence may have exacerbated the graben and scarps in case of South Wales. Both the South Wales and Pennine graben appear to fall into the category 'complex spreads' as described by Cruden \& Varnes (1996) and Brunsden at al., (1996). However, the terms 'block' or 'rock' also apply, and a therefore the most appropriate term to describe these features may be 'complex block spreads' or 'complex rock block spreads.' However, further detailed investigation and recognition of these phenomena are warranted to reduce the likelihood of confusion in terminology and confirm the accurate classification and mechanisms of these movements.

\section{Acknowledgements}

This paper has been published with the permission of IMC Group Consulting Ltd, the British Geological Survey (NERC) and Halcrow Group Ltd.

\section{References}

Aldabbagh, T. H. and Crips, J. C. (1987). Data sources for planning: Morphological mapping of landslides in north-east Derbyshire. In: Planning in Engineering Geology, Engineering Geology Special Publication No.4, Geological Society, London, 101-114.

Bovis, M. J. (1982). Uphill-facing (antislope) scarps in the Coast Mountains Southwest British Columbia. Geological Society of America, 93, 804-812.

Brusden, D., Coombe, K., Goudie, A. S. and Parker, A. G. (1996). The structural geomorphology of the Isle of Portland, Southern England. Proceedings of the Geologists Association, 107, 209-230.

Cancelli, A. and Pellegrini, M. (1987). Deep-seated gravitational deformation in Northern Apennines, Italy. $5^{\text {th }}$ International Conference \& Field Workshop on Landslides. Australia \& New Zealand, $1^{\text {st }}-12^{\text {th }}$ August, 1-8.

Conway, B. W., Forster, A., Northmore, K. J. and Barclay, W. (1980). South Wales Coalfield Landslip Survey. Report of the Institute of Geological Sciences Special Surveys Division Engineering. Geology Unit, Report No. EG80/4.

Cripps, J. C. and Hird, C. C. (1997). A Guide to the Landslide at Mam Tor. Geoscientist, 2, No. 3, 22-27. 
Cruden, D. M. and Varnes, D, J. (1996). Landslide type and processes. In: Turner, A. K. \& Schuster, R. L. (eds). Landslides, investigation and mitigation. Special report 247, Transport Research Board, National Research Council. National Academy press, Washington D.C., 36-75.

Crozier, M. J. (1986). Landslides: causes, consequences and environment. Croom Helm, London: Sydney; Dover, New Hampshire.

Davenport, C. A., Ringrose, P. S., Becker, A., Hancock, P and Fenton, C. (1989). Geological investigations of late and post glacial earthquakes activity in Scotland. In: Gregersen., S. and Basham, P. W. (eds). Earthquakes at North-Atlantic Passive Margins: Neotectonics and Postglacial Rebound, 174-194.

Doornkamp, J. C. (1990). Landslides in Derbyshire. The East Midlands Geographer, 13, part 2, 33-63

Donnelly, L. J. (1994). Predicting the Reactivation of Geological Faults and Rock Mass Discontinuities During Mineral Exploitation, Mining Subsidence and Geotechnical Engineering. PhD Thesis, University of Nottingham, British Coal Corporation Industrial Sponsorship.

Donnelly, L. J., Northmore, K. and Jermy C. N. (2000a). Fault Reactivation in the Vicinity of Landslides in South Wales, UK. ISSMGE \& BGS 8th International Symposium on Landslides, Cardiff, Volume 1 481-486.

Donnelly, L. J., Northmore, K. and Siddle, H. L. (2000b). Landslides and Landslide Management in South Wales. In: Siddle, H.J., Bromhead, E. N. and Bassett, M. G. (eds). (2000). Landslides and Landslide Management in South Wales. National Museum of Wales, Geological Series No.18, Cardiff.

Donnelly, L. J. (2000c). The reactivation of geological faults during mining subsidence from 1859 to 2000 and beyond. Transactions of the Institution of Mining and Metallurgy, 109, September-December 2000, A179-A190.

Halcrow, Sir William (1989). Landslides and Undermining Research Project. Landslide Inventory. Joint project undertaken by Sir William Halcrow \& Partners Ltd and Nottingham University, of Mining Engineering. Report for Department of the Environment and Welsh Office..

Higginbottom, I. E \& Fookes, P. G. (1971). Engineering aspects of periglacial features in Britain. Quarterly Journal of Engineering Geology, 3, 85-117.

Hutchinson, J. N. (1988). Morphological and geotechnical parameters of landslides in relation to geology and hydrogeology. Proceedings of 5th International Symposium on Landslides, Lausanne, 3-35.

Hutchinson, J. N. (2001). The Fourth Glossop Lecture. Reading the Ground: Morphology and Geology in Site Appraisal. Quarterly Journal of Engineering Geology and Hydrogeology, 34, 2, 5-50.

Johnson, R. H. and Vaughan, R. D. (1993). The Alport Castles, Derbyshire: A south Pennine slope and its geomorphic history. East Midlands Geographer, 8, 79-88.

Knill, J. L, (1970). Environmental, economic and engineering factors in the selection of reservoir sites, with particular reference to Northern England. In Warren, P. T. (ed), Geological Aspects of Development and Planning in Northern England. Yorkshire Geological Society, 124-143.

Kujansuu, R. (1964). Recent faults in Finnish Lapland. Geologi, 16, 30.

Lagerback, R. (1979). Neotectonic structure in northern Sweden. Geologi Foren, Stockholm Fourhand., 100(3), 263-668.

Lundqvist, J and Lagerback, R. (1976). The Parve Fault: A late glacial fault in the Precambrian of Swedish Lapland. Geol. Foren. Forhand., 98, 45-51.

McArthur, J L. 1977. Quaternary erosion in the upper Derwent basin and its bearing on the age of surface features in the southern Pennines. Trans. Inst. Brit. Geogr. 2, 490-497.

Morner, N. A. (1978). Faulting, fracturing and seismicity as functions of glacio-isostasy in Fennoscandia. Geology, 6(1), 41-45.

Ringrose, P. R. (1987). Fault Activity and Palaeoseismicity During Quaternary Times in Scotland. Ph.D. Thesis, University of Strathclyde, Glasgow.

Skempton, A. W., Leadbeater, A. D. and Chandler, R. J. (1989). The Mam Tor Landslide, North Derbyshire. Philosophical Transactions of the Royal Society London, series A, 329, Number 1607, 503-547.

Stewart, H. F and Cripps, J. C. (1983). Some engineering implications of chemical weathering of pyritic shale. Quarterly Journal of Engineering Geology,16, 281-9.

Stevenson, I. P. and Gaunt, G. D. (1971). Geology of the country around Chapel-en-le-Frith, Memoirs of the Geological Survey of Great Britain, London.

Waltham, A. C. \& Dixon, N. (2000). Movement of the Mam Tor Landslide, Derbyshire, UK. Quarterly Journal of Engineering Geology and Hydrogeology, 33, 2, 105-123. 